\title{
Analisis Disparitas Harga dan Korelasi terhadap Dana Desa: Studi Kasus Bawang Merah dan Cabai Merah
}

\author{
Dian Verawati Panjaitan ${ }^{1 *}$, Tanti Novianti ${ }^{1}$, Muhammad Fazri ${ }^{2}$, Sri Retno Wahyu Nugraheni ${ }^{1}$ \\ ${ }^{1}$ Departemen Ilmu Ekonomi,Fakultas Ekonomi dan Manajemen, Institut Pertanian Bogor \\ Jalan Agatis, Kampus Darmaga, Bogor 16680, Indonesia \\ ${ }^{2}$ Kementerian Desa, Pembangunan Daerah Tertinggal, dan Transmigrasi \\ "Korespondensi: fadhian@yahoo.co.id
}

[diterima: Agustus 2018- revisi: Desember 2018-diterbitkan daring: Juli 2019]

\begin{abstract}
ABSTRAK
Kesenjangan harga merupakan masalah penting bagi Indonesia karena biaya transportasi dan biaya produksi. Harga cabai dan bawang merah relatif berfluktuasi antar waktu dan antar wilayah. Keduanya memiliki peran penting untuk dikonsumsi dan digunakan dalam industri makanan dan non-makanan. Pemerintah telah menerapkan beberapa kebijakan untuk mengurangi perbedaan harga antar daerah seperti tol laut dan infrastruktur: jalan, jembatan, dan sistem irigasi yang menggunakan dana desa. Studi ini meneliti hubungan atau kolerasi antara dana desa dengan perbedaan harga terhadap perbedaan harga di pasar cabai dan bawang merah di tingkat provinsi. Temuan menunjukan bahwa kesenjangan harga antar provinsi masih terjadi, terutama di wilayah timur dan barat. Papua adalah provinsi dengan harga cabai merah dan bawang merah tertinggi. Studi ini juga menemukan tidak ada korelasi antara dana desa dengan disparitas harga bawang merah dan cabai merah.
\end{abstract}

Kata Kunci: disparitas, cabai, bawang merah, harga, dana desa

\begin{abstract}
Price disparity is a crucial issue for Indonesia due to transportation cost and production cost. The prices of chili and shallot are rellatively fluctuating between times and between regions. Both of them have an important role to consume and use in both food and non-food industries. The government has implemented several policies to reduce price disparity between regions such as sea toll and infrastructure: rood, bridge, and irrigation systems which used village funds. This study examines the impact of village funds to the price disparity in chili and shallot market at provincial lavel. The findings show that price disparities between provinces still occur, especially in the eastern and western regions. Papua is a province with the highest prices in both commodities. The study also found no correlation between the village funds and the price of chili and shallot.
\end{abstract}

Keywords: disparity, chili, shallot, price, village funds

JEL Classification: D13, Q02, Q11, Q28 


\section{PENDAHULUAN}

Harga beberapa barang terutama produk pertanian menunjukkan fluktuasi dari musim ke musim. Ketidakstabilan harga tersebut dapat disebabkan oleh fluktuasi penawaran dan ketidakstabilan permintaan (Sukirno 2005). Produksi sektor pertanian dipengaruhi oleh teknologi, kondisi iklim yang memengaruhi jumlah curah hujan (musim hujan atau musim kemarau), dan serangan hama. Dari sisi permintaan, harga komoditas pertanian cenderung fluktuatif karena permintaan terhadap komoditas pertanian bersifat inelastis (merupakan barang kebutuhan pokok). Walaupun harganya sangat meningkat namun jumlah yang sama masih tetap harus dikonsumsi. Sebaliknya pada waktu harga menurun, konsumsi tidak akan banyak bertambah karena kebutuhan konsumsi yang relatif tetap. Oleh karena sifat permintaan atas barang pertanian yang tidak elastis tersebut, maka harga akan mengalami perubahan yang sangat besar sekiranya penawaran hasil pertanian mengalami perubahan.

Harga komoditas bahan makanan pokok sering kali memiliki andil yang besar terhadap inflasi nasional. Selain beras, komoditas seperti bawang merah dan cabai merah juga dominan menyumbang inflasi. Pada tahun 2016, harga cabai merah menyumbang 0.35 persen dalam pembentukan inflasi nasional. Sedangkan bawang merah menyumbang sebesar 0.17 persen, jauh lebih besar dibandingkan tarif angkutan udara ( 0.13 persen) dan bawang putih (0.11 persen). Komoditi lain yang menyumbang inflasi pada tahun ini adalah ikan segar, rokok kretek, tarif sewa rumah yang masing-masing memiliki andil 0.09 persen.

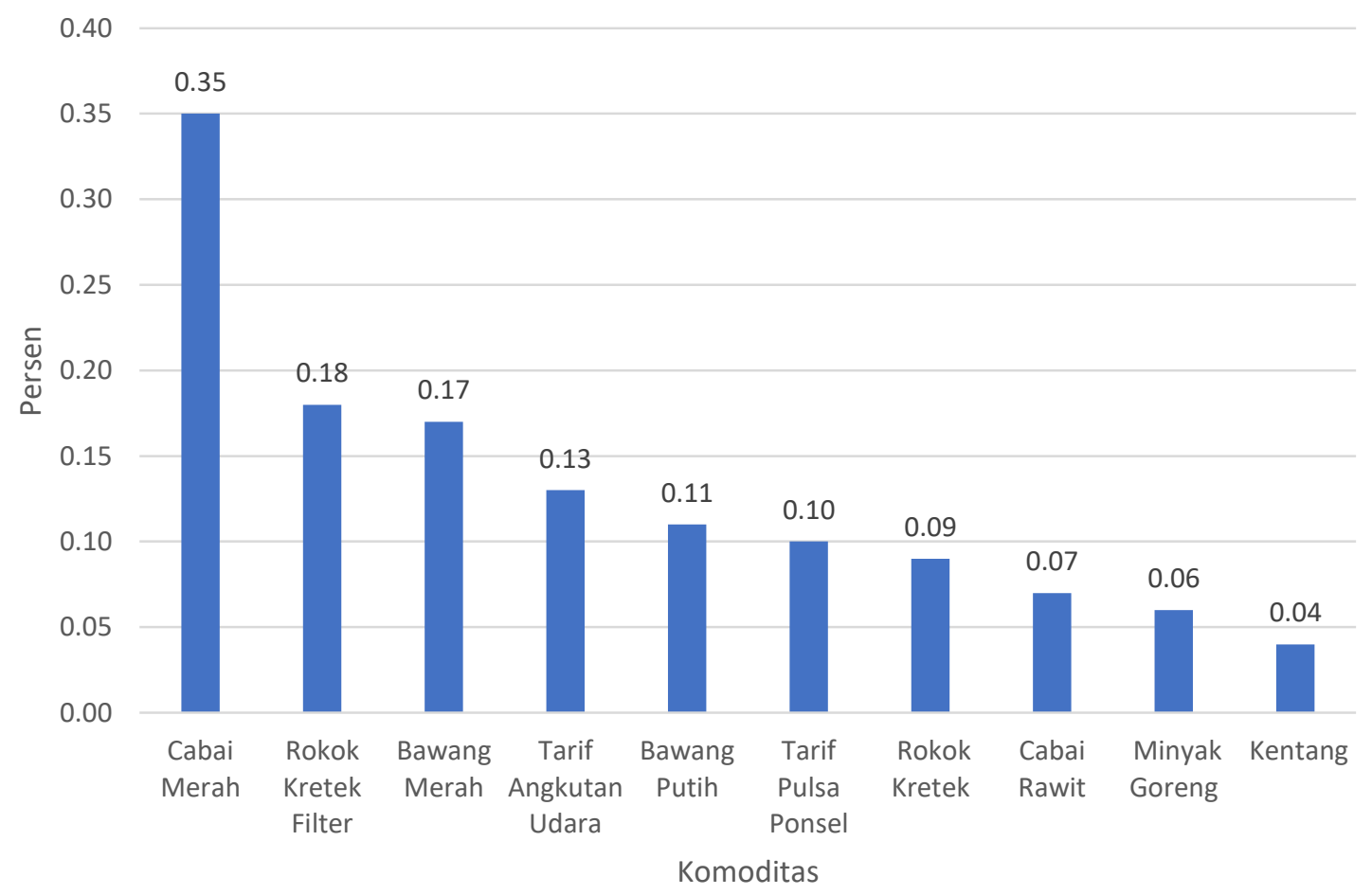

Sumber: BPS, 2018

Gambar 1. Andil Beberapa Komoditas yang Dominan Terhadap Inflasi Nasional Pada Tahun 2016

Cabai merah dan bawang merah merupakan dua komoditas hortikultura khususnya sayuran yang memilik peran dan prospek ekonomi maupun sosial yang sangat penting. Peran penting dari komoditas ini antara lain sebagai berikut : (1) komoditas pokok untuk konsumsi sehari-hari, yang mengandung gizi dan mineral (2) sumber pendapatan bagi petani dan buruh tani, dan (3) sebagai sumber devisi negara non migas. Kedua komoditas ini sering mengalami volatilitas harga yang berpengaruh terhadap inflasi maupun deflasi nasional. Inflasi tertinggi 
pada tahun 2016 terjadi pada bulan Juli sebesar 0.69 persen dan deflasi tertinggi pada bulan April yakni sebesar 0.45 persen. Cabai merah dan bawang merah adalah salah satu komoditas yang dominan memberikan andil/sumbangan inflasi dan deflasi pada bulan tersebut (BPS 2018).

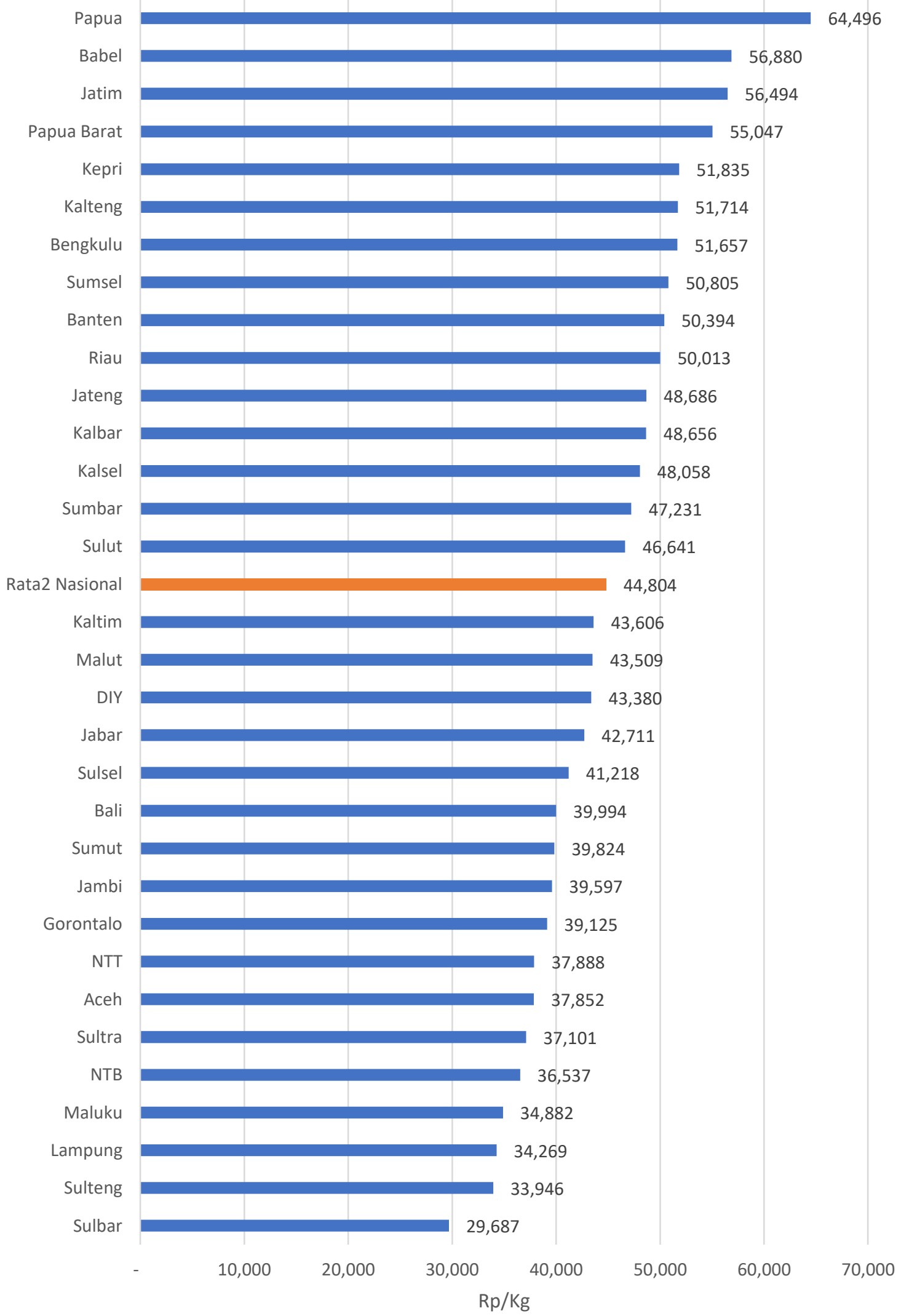

Sumber: BPS, 2016

Gambar 2. Perkembangan Harga Produsen dan Konsumen Cabai Merah Tahun 2016. 
Demikian juga harga antar produsen dan konsumen cenderung berfluktuasi. Pergerakan harga di tingkat produsen tidak selalu sejalan dengan di tingkat konsumen. Secara rata-rata nasional perkembangan harga di tingkat produsen maupun konsumen selama tahun 2008-2012 menunjukkan kecenderungan meningkat, namun volatilitas harga di tingkat konsumen jauh lebih tinggi (Gambar 3).

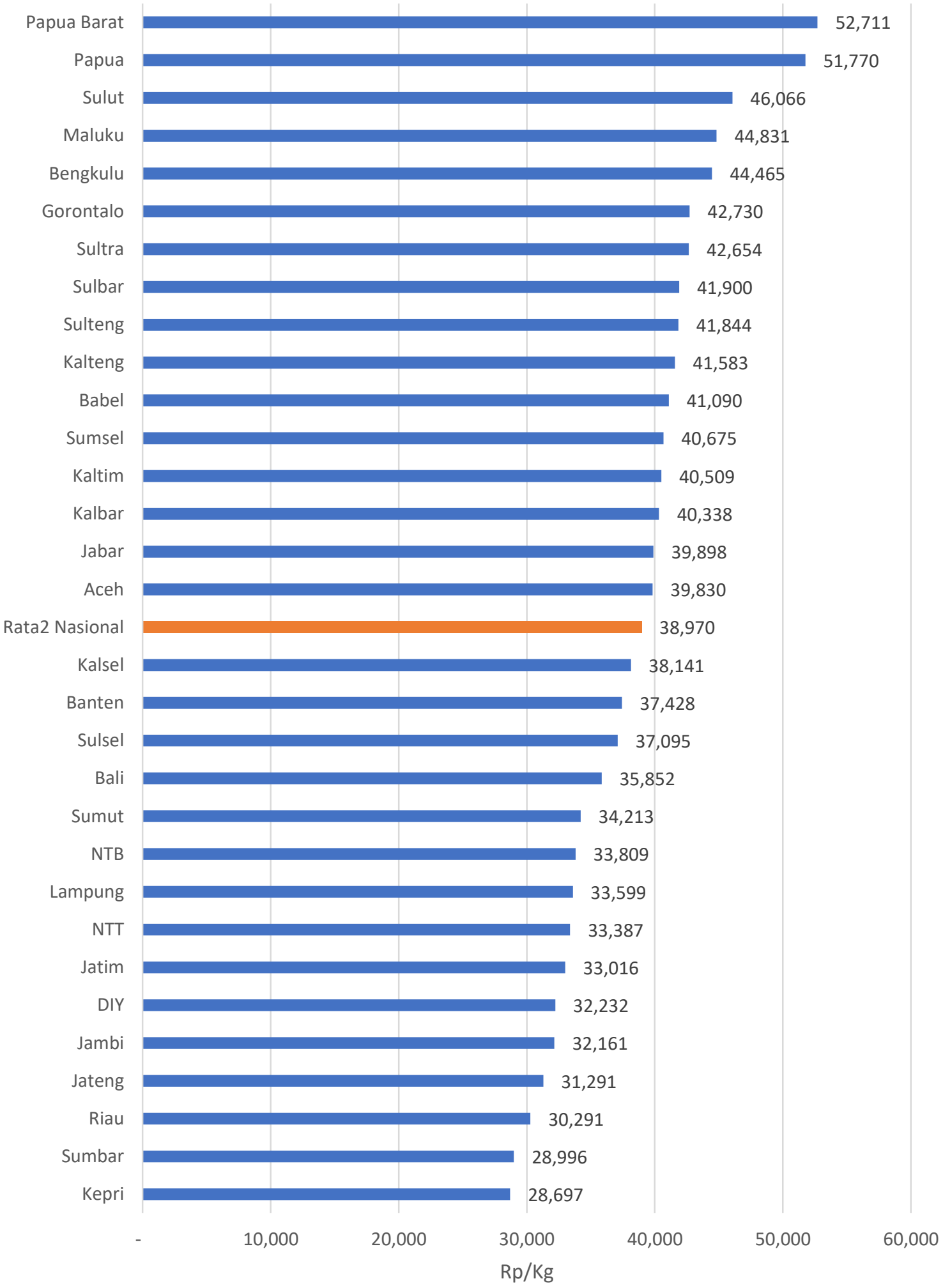

Sumber :BPS, 2016

Gambar 3. Perkembangan Rata-rata Harga Bawang Merah Tahun 2016. 
Harga bawang merah tingkat produsen relatif tidak seragam antar provinsi. Harga bawang merah tingkat produsen yang tinggi terjadi di wilayah Papua, Sulawesi, Maluku dan Kalimantan. Rata-rata harga bawang merah tingkat eceran berfluktuasi selama periode tahun 2010 sampai 2014 dari Rp 16 852/kg sampai Rp 36 318/kg. Pada tahun 2013 harga bawang merah relatif melonjak lebih dari 100 persen dibandingkan tahun 2012. Rata-rata harga bawang merah selama periode tersebut sebesar Rp 21 436/kg.

Volatililitas cabai merah dan bawang merah ini selain disebabkan karena faktor musim, ketidakseimbangan pasokan (produksi) dan permintaan (konsumsi). Terkait permintaan, kebutuhan masyarakat akan kedua komoditas ini relatif stabil, sementara terkait faktor supply sangat dipengaruhi oleh faktor spasial diantaranya perbedaan harga antar wilayah dan tingkat produksi di masing-masing wilayah sentra produksi. Disamping produksi pangan yang tidak mencukupi, kurang meratanya penyediaan pangan bagi masyarakat juga menjadi pemicu kenaikan harga pangan. Fakta di lapangan menunjukkan bahwa sistem produksi dan sistem distribusi beberapa pangan terganggu karena kualitas sarana dan prasarana transportasi banyak rusak.

Indonesia sebagai negara kepulauan menyebabkan proses distribusi yang menjadi sulit. Letak pasar konsumen bahan pangan yang yang terpisah sangat jauh dengan daerah produksi dan tidak berimbangnya jumlah produksi dan konsumsi membuat tingginya biaya perdagangan menyebabkan lemahnya integrasi pasar komoditi pangan. Pada pasar yang terintegrasi dengan hubungan perdagangan yang baik, penerapan intervensi pemerintah dalam meredam fluktuasi harga dapat disalurkan kepada pasar-pasar lainnya. Pelaksanaan kebijakan harga dapat dilakukan dengan biaya yang lebih murah, sehingga apabila terjadi gejolak harga disuatu daerah dapat dilakukan aksi efektif agar gejolak harga tersebut tidak meluas dan menjadi gejolak nasional.

Untuk itu, pemerintah telah melakukan kebijakan seperti pembangunan tol laut, transportasi multimoda, dan pemberian dana desa. Salah satu tujuan kebijakan-kebijakan tersebut adalah mengurangi rantai tata niaga, memperlancar distribusi dan mengurangi biaya produksi yang akan berpengaruh pada harga. Beberapa penelitian terkait hal ini telah dilakukan, diantaranya oleh Juniati (2017) melakukan analisis pengaruh transportasi multimoda terhadap disparitas harga di Provinsi Papua Barat. Hasil yang didapat bahwa minimnya infrastruktur transportasi baik di laut dan udara menyebabkan tingginya harga yang diterima di Daerah Papua Barat dibandingkan dengan Nasional. Gangguan transportasi akan berpengaruh terhadap pasokan dan harga pangan menunjukkan lemahnya manajemen pelaksanaan pembangunan daerah oleh pemerintah bersama pemerintah daerah setempat serta belum sinergisnya dengan budaya (kulutur) lokal, dan kurang koordinasi antara pemerintah daerah dengan tokoh adat dalam proses pembangunan jalan, pelabuhan dan bandara.

Secara garis besar penelitian-penelitian sebelumnya menunjukkan bahwa dengan adanya transportasi yang lebih efisien maka akan mengurangi disparitas sehingga transportasi multimoda menjadi suatu pilihan pasti untuk mengurangi disparitas harga. Dukungan pemerinah selanjutnya adalah pemberian dana desa yang salah satunya diharapkan dapat menjadi sumber pendanaan infrastuktur desa seperti jalan. Menurut LIPI (2017), tol laut saja tentu belum berhasil menurunkan disparitas harga. Untuk itu, kebijakan tol laut ini harusnya juga diimbangi dengan pembangunan konektivitas dari pedesaan ke akses transportasi. Ini digunakan untuk menekan biaya transportasi yang mahal dari pelabuhan menuju pemukiman terdalam.

Prioritas penggunaan dana desa menurut Permen No. 16 Tahun 2018 dan Permendes, PDT dan Transmigrasi No.19/2017 tersebut salah satunya adalah untuk pembangunan infrastruktur desa semisal irigasi desa, talud dan drainase. Adanya dana desa ini diharapkan dapat mendukung pembangunan infrastruktur di desa. Menurut LIPI (2017), kebijakan tol laut masih belum berhasil menekan disparitas harga di Indonesia Timur, khususnya pada bahan pangan. Hal itu terlihat dari observasi badan penelitian itu sejak Juli 2016 hingga Agustus 2017. LIPI menggunakan harga bahan pangan 
di Surabaya, Jawa Timur sebagai harga patokan dalam penelitian tersebut. Pasalnya, Surabaya merupakan basis pelabuhan proyek tol laut yang melayani pengiriman logistik ke 13 rute menuju Indonesia timur.

Adapun, barang logistik ini disalurkan ke sembilan provinsi yang tergolong sebagai wilayah Indonesia Timur yakni Sulawesi Utara, Sulawesi Selatan, Sulawesi Tenggara, Nusa Tenggara Barat, Nusa Tenggara Timur, Maluku, Maluku Utara, Papua Barat, dan Papua. Di samping itu, di dalam penelitian ini, LIPI mengonversi disparitas antara harga patokan Surabaya dengan harga bahan pangan di masing-masing provinsi ke dalam satuan ukur yang digunakan komoditas tersebut.

Hasilnya, Sulawesi Selatan adalah provinsi disparitas terendah dan disparitas tertinggi ditempati oleh Papua. Disparitas harga ini masih sama jika dibanding periode yang sama tahun sebelumnya. Menurutnya, masalah disparitas harga ini bukan karena program tol lautnya, melainkan sistem distribusi dari produsen ke pelabuhan (door-to-port) dan pelabuhan ke konsumen (port-to-door) yang tidak efisien. Sulawesi Selatan bisa jadi provinsi dengan disparitas terendah karena sebagian besar tinggal di pesisir yang memiliki akses ke pelabuhan. Di sisi lain, disparitas Papua masih tinggi karena sebagian besar barang dari pelabuhan masih harus dikirim ke pedalaman yang tentu saja costly.

Alokasi Dana Desa tersebut dipergunakan antara lain untuk membiayai penyelenggaraan administrasi desa (30 persen) dan sisanya digunakan untuk pelaksanaan pembangunan desa, pembiayaan kemasyarakatan desa dan pemberdayaan masyarakat desa. Berdasarkan alokasi Dana Desa tersebut, maka tiap kabupaten atau kota mengalokasikannya kepada setiap desa berdasarkan jumlah desa dengan memerhatikan jumlah penduduk (30 persen), luas wilayah (20 persen) dan angka kemiskinan (50 persen).

Alokasi Dana Desa yang meningkat setiap tahun membawa pengaruh baik secara langsung (pertumbuhan ekonomi) dan tidak langsung (peningkatan kualitas dasar hidup masyarakat desa) terhadap pembangunan desa. Tiga tahun implementasi dana desa, data mencatatkan hasil pembangunan yang signifikan seperti pembangunan dan perbaikan jalan desa, pembentukan Badan Usaha Milik Desa (BUMDes), embung, unit air bersih, dan polindes serta infrastruktur lainnya. Mahfudz (2009) turut menyatakan bahwa besaran Dana Desa memiliki manfaat, dampak positif dan multiplier effect yang signifikan dalam perbaikan infrastruktur, peningkatan pengetahuan masyarakat, meningkatnya partisipasi masyarakat dalam pembangunan desa dan banyaknya tenaga kerja yang diserap (Fazri et al 2019).

Ternyata, tol laut saja tentu belum berhasil menurunkan disparitas harga. Diperlukan adanya kebijakan pembangunan konektivitas dari pedesaan ke akses transportasi. Ini digunakan untuk menekan biaya transportasi yang mahal dari pelabuhan menuju pemukiman terdalam. Jika masalah konektivitas darat ini dapat diatasi, diharapakan dapat mengurangi disparitas harga. Oleh karena itu, tujuan dari penelitian ini adalah

1. Menghitung tingkat disparitas harga bawang merah dan cabai merah di level nasional.

2. Mengetahui bagaimana hubungan (korelasi) antara dana desa terhadap disparitas harga bawang merah dan cabai merah.

\section{METODE PENELITIAN}

\section{Jenis dan Sumber Data}

Data yang digunakan dalam penelitian ini merupakan data sekunder yang diperoleh Badan Pusat Statistik (BPS) terutama data harga bawang merah dan cabai merah, Kementrian Desa, Pembangunan Daerah Tertinggal, dan Transmigrasi untuk data dana desa serta dari penelusuran literatur, website, dan penelitian terdahulu. Data yang digunakan adalah data sekunder harga bawang merah dan cabai merah pada tahun 2013-2017. Sedangkan data dana desa yang digunakan adalah selama periode 2015-2017.

\section{Metode Analisis}

Metode analisis yang digunakan untuk menjawab tujuan ini adalah analisis kuantitatif deskriptif. Analisis kuantitatif deskriptif digunakan untuk mengetahui tingkat disparitas harga bawang merah dan cabai merah. 
Sedangkan analisis korelasi digunakan untuk menganalisis pengaruh dana desa terhadap disparitas harga kedua komoditi tersebut.

\section{Analisis Korelasi}

Analisis korelasi digunakan untuk menjawab tujuan kedua yaitu untuk mengetahui bagaimana hubungan antara dana desa dengan disparitas harga. Korelasi merupakan istilah yang biasa digunakan untuk menggambarkan ada tidaknya hubungan suatu hal dengan hal lain. Secara sederhana memang seperti itulah pengertian korelasi. Analisis korelasi adalah suatu cara atau metode untuk mengetahui ada atau tidaknya hubungan linear antar variabel. Apabila terdapat hubungan maka perubahan-perubahan yang terjadi pada salah satu variabel $\mathrm{X}$ akan mengakibatkan terjadinya perubahan pada variabel lainnya (Y). Istilah tersebut dikatakan istilah sebab akibat, dan istilah tersebut menjadi ciri khas dari analisis korelasi.

Apabila antara dua variabel (X dan Y) yang masing-masing mempunyai skala pengukuran sekurang-kurangnya interval (ratio) dan hubungannya merupakan hubungan linear, maka keeratan hubungan antara kedua variabel itu dapat dihitung dengan menggunakan formula korelasi Pearson yang diberi symbol dengan $r_{y x}$ dan $r_{x y}$ untuk sample $p_{y x}$ dan $p_{x y}$ untuk populasi.

Koefisien korelasi Pearson antara dua variabel yang datanya tidak berkelompok :

$$
\begin{gathered}
\mathrm{r}_{\mathrm{yx}} \text { atau } \mathrm{rxy}=\frac{\sum_{i=1}^{n}\left(x_{i}-\bar{x}\right)\left(y_{i}-\bar{y}\right)}{\sqrt{\sum_{i=1}^{n}\left(x_{i}-\bar{x}\right)^{2} \sum_{i=1}^{n}\left(y_{i}-\bar{y}\right)^{2}}} \text { atau } \\
\mathrm{r}=\frac{n \sum_{i=1}^{n} x_{i} y_{i}-\sum_{i=1}^{n} x_{i} \sum_{i=1}^{n} y_{i}}{\sqrt{n \sum_{i=1}^{n} x_{i}^{2}-\left(\sum_{i=1}^{n} x_{i}\right)^{2}} \sqrt{n \sum_{i=1}^{n} y_{i}^{2}-\left(\sum_{i=1}^{n} y_{i}\right)^{2}}}
\end{gathered}
$$

\section{Analisis Disparitas}

Disparitas secara nasional diukur dengan besaran koefisien variani $(\mathrm{kV})$, dengan rumus:

$$
K V=\frac{S S}{\bar{x}} \times 100 \text { persen }
$$

Dimana :

$\mathrm{KV} \quad=$ koefisien variasi

SS $=$ simpangan standar

$\bar{x} \quad=$ rata-rata nasional

Kategori disparitas untuk lingkup nasional adalah:

Rendah $\quad=\mathrm{kV}<10$ persen

Sedang $\quad=10$ persen $\leq \mathrm{kV}<20$ persen

Tinggi $\quad=20$ persen $\leq \mathrm{kV}<30$ persen

Sangat tinggi $=k V \geq 30$ persen

Sedangkan Disparitas provinsi diukur dengan simpangan rata-rata harga provinsi dibandingkan dengan rata-rata nasional, dengan rumus:

$$
S S=\sqrt{\frac{\sum_{i=1}^{n}\left(X_{i}-\bar{X}\right)^{2}}{n}}
$$

Dimana :

$\mathrm{X}=$ harga pada tingkat provinsi

$\bar{x} \quad=$ rata-rata nasional

$\mathrm{KV}=(\mathrm{SS} / \mathrm{X}) * 100$ persen

Kategori disparitas untuk lingkup provinsi adalah:

Tidak Kritis $\quad=\mathrm{kV}=0$

Rendah $\quad=\mathrm{kV}<10$ persen

Sedang $\quad=10$ persen $\leq \mathrm{kV}<20$ persen

Tinggi $\quad=20$ persen $\leq \mathrm{kV}<30$ persen

Sangat tinggi $=\mathrm{kV} \geq 30$ persen

Disparitas harga terbentuk dikarenakan proses distribusi dari produsen ke konsumen. Istilah sistem distribusi sama dengan tata niaga yaitu suatu kegiatan ekonomi yang berfungsi membawa atau menyampaikan barang dan jasa dari produsen ke konsumen. Marjin pemasaran timbul karena adanya pelaku dalam tata niaga sebuah komoditi/barang yang mengambil keuntungan atas biaya yang dikeluarkannya karena proses mengumpulkan atau menyalurkan barang/komoditi tersebut. Marjin yang diambil menjadi lebih besar jika pelaku yang bersangkutan melakukan aktivitas peningkatan nilai tambah terhadap barang/komoditi tersebut, misalnya sortasi, grading atau pengolahan. Dahl dan Hammond dalam Widia (2011) menyatakan bahwa, marjin distribusi sebagai perbedaan harga di tingkat petani dengan harga di tingkat pengecer. Marjin distribusi hanya menunjukkan perbedaan harga dan tidak menunjukkan jumlah produk yang dipasarkan. Marjin pemasaran 
berperan dalam pembentukan disparitas harga antar daerah.

\section{HASIL DAN PEMBAHASAN}

\section{Realisasi Penggunaan Dana Desa}

Desa setiap tahunnya dianggarkan dalam APBN yang diberikan ke setiap desa sebagai salah satu sumber pendapatan desa. Kebijakan ini sekaligus mengintegrasikan dan mengoptimalkan seluruh skema pengalokasian anggaran dari pemerintah kepada desa yang selama ini sudah ada. Dengan adanya dana desa diharapkan dapat meningkatkan pelayanan publik desa, mengentaskan kemiskinan, memajukan perekonomian desa, mengatasi kesenjangan pembangunan antar desa serta memperkuat masyarakat desa sebagai subjek pembangunan (Kementerian Keuangan 2017).

Desa memiliki beberapa sumber pendapatan, yaitu pendapatan asli desa, dana desa yang bersumber dari APBN, bagian dari PDRD Kabupaten/Kota, alokasi dana desa dari Kabupaten/Kota, bantuan keuangan dari APBD Provinsi dan APBD Kabupaten/Kota, Hibah dan sumbangan pihak ke-3 serta lain-lain pendapatan yang sah. Salah satu pendapatan desa, yakni dana desa merupakan dana APBN yang diperuntukkan bagi desa yang ditransfer melalui APBD Kabupaten/Kota dan diprioritaskan untuk pelaksanaan pembangunan dan pemberdayaan masyarakat desa. Dana desa dialokasikan dengan memerhatikan jumlah penduduk (30 persen), angka kemiskinan (50 persen), luas wilayah dan tingkat kesulitan geografis (20 persen).

Adapun tujuan dialokasikannya dana desa adalah untuk meningkatkan pelayanan publik di desa, mengentaskan kemiskinan, memajukan perekonomian desa, mengatasi kesenjangan pembangunan antar desa dan memperkuat masyarakat desa sebagai subjek dari pembangunan. Berdasarkan Peraturan Menteri Keuangan Nomor 199 Tahun 2017 pengalokasian Dana Desa di setiap Kabupaten/Kota harus memperhatikan beberapa aspek, yaitu:

1. Pagu Alokasi Dasar

2. Pagu Alokasi Afirmasi

3. Status Desa Tertinggal dan Desa sangat tertinggal

4. Data jumlah penduduk miskin
5. Desa tertinggal dan Desa sangat tertinggal yang memiliki jumlah penduduk miskin tinggi, yaitu desa sangat tertinggal yang memiliki jumlah penduduk miskin terbanyak yang berada pada desil ke 8, 9 dan 10 berdasarkan perhitungan yang dilakukan oleh Direktorat Jenderal Perimbangan Keuangan.

6. Pagu Alokasi Formula dibagi berdasarkan jumlah penduduk desa, angka penduduk miskin desa, luas wilayah desa, dan tingkat kesulitan geografis.

Pada tahun 2015 - 2017, dana desa dibagi dengan bobot sebesar 90 persen untuk alokasi dasar dan 10 persen untuk alokasi formula. Implikasi yang terjadi dengan pengalokasian dana desa dengan menggunakan formulasi tersebut adalah belum sepenuhnya mencerminkan (i) keadilan; (ii) keberpihakan kepada desa tertinggal dan desa sangat tertinggal; dan (iii) dan belum sepenuhnya fokus pada upaya pengentasan kemiskinan. Oleh karena itu pada tahun 2018, dilakukan reformulasi pengalokasian dana desa dengan menurunkan proporsi untuk alokasi dasar yang sebelumnya 90 persen menjadi 77 persen, sedangkan untuk alokasi afirmasi dari 10 persen menjadi 20 persen serta menambahkan alokasi afirmasi untuk desa tertinggal dan desa sangat tertinggal sebesar 3 persen dan mengubah bobot masing-masing variabel agar mendukung penurunan kemiskinan dan ketimpangan.

Delam et al (2016) menjelaskan bahwa penggunaan dana desa diatur dengan Peraturan Menteri Keuangan Republik Indonesia Nomor 93/PMK.07/2015 tentang Tata Cara Pengalokasian, Penyaluran, Penggunaan, Pemantauan dan Evaluasi Dana Desa dan Peraturan Menteri Desa, Pembangunan Daerah Tertinggal, dan Transmigrasi Nomor 5 Tahun 2015 Tentang Penetapan Prioritas Penggunaan Dana Desa Tahun 2015. Kedua peraturan ini memuat tentang prioritas penggunaan dana desa oleh masyarakat. Pada Bab IV Peraturan Menteri Keuangan Nomor 93/PMK.07/2015 pasal 21 ayat 1 menyebutkan bahwa dana desa dapat dimanfaatkan untuk membiayai penyelenggaraan pemerintahan, pembangunan, pemberdayaan masyarakat, dan kemasyarakatan. Kemudian ayat 2 bahwa penggunaan dana desa diprioritaskan untuk pembangunan dan pemberdayaan masyarakat. Selanjutnya Pasal 23 
mengamanahkan bahwa dana desa dapat digunakan untuk membiayai kegiatan yang tidak termasuk kegiatan prioritas setelah mendapat persetujuan bupati/walikota.

Persetujuan diberikan apabila alokasi anggaran untuk pembangunan dan pemberdayaan masyarakat sudah terpenuhi. Peraturan Menteri Desa, Pembangunan Daerah Tertinggal, dan Transmigrasi Nomor 5 Tahun 2015 juga mengatur tentang Penetapan Prioritas Penggunaan Dana Desa Tahun 2015, karena peraturan ini merupakan penjabaran dari Peraturan Menteri Keuangan Nomor 93 Tahun 2015, maka peraturan ini lebih detail seperti pada BAB II yang mengatur Prinsip Penggunaan Dana Desa. Dana Desa yang bersumber dari APBN digunakan untuk mendanai pelaksanaan kewenangan berdasarkan hak asal usul dan kewenangan lokal berskala desa yang diatur dan diurus oleh desa (pasal 2). Selanjutnya Pasal 3 dan 4 menyebutkan dana desa diprioritaskan untuk membiayai belanja pembangunan dan pemberdayaan masyarakat desa dan penggunaannya tertuang dalam prioritas belanja desa yang disepakati dalam musyawarah desa.

Prioritas penggunaan dana desa untuk pembangunan desa dialokasikan untuk mencapai tujuan pembangunan desa, yaitu meningkatkan kesejahteraan masyarakat desa dan kualitas hidup manusia serta penanggulangan kemiskinan, melalui (a) pemenuhan kebutuhan dasar, (b) pembangunan sarana dan prasana desa, (c) pengembangan potensi ekonomi lokal, dan (d) pemanfaatan sumber daya alam dan lingkungan secara berkelanjutan (pasal 5).

Sedangkan, prioritas penggunaan dana desa untuk pemberdayaan masyarakat desa terutama untuk penanggulangan kemiskinan dan peningkatan akses atas sumber daya ekonomi, sejalan dengan pencapaian target RPJM Desa dan RKP Desa setiap tahunnya, yang diantaranya dapat mencakup (a) peningkatan kualitas proses perencanaan Desa, (b) mendukung kegiatan ekonomi baik yang dikembangkan oleh BUM Desa maupun oleh kelompok usaha masyarakat Desa lainnya, (c) pembentukan dan peningkatan kapasitas Kader Pemberdayaan Masyarakat Desa, (d) pengorganisasian melalui pembentukan dan fasilitas paralegal untuk memberikan bantuan hukum kepada warga masyarakat desa, (e) penyelenggaraan promosi kesehatan dan gerakan hidup bersih dan sehat, (f) dukungan terhadap kegiatan desa dan masyarakat pengelolaan hutan desa dan hutan kemasyarakatan, dan (g) peningkatan kapasitas kelompok masyarakat melalui (a) kelompok usaha ekonomi produktif, (b) kelompok perempuan, (c) kelompok tani, (d) kelompok masyarakat miskin, (e) kelompok nelayan, (f) kelompok pengrajin, (g) kelompok pemerhati dan perlindungan anak, (h) kelompok pemuda; dan (i) kelompok lain sesuai kondisi desa.

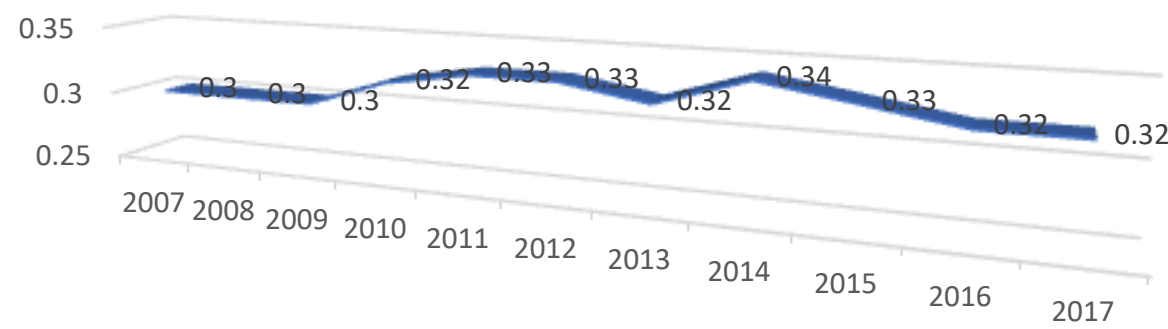

Sumber: Kemenkeu, 2017

Gambar 4. Perkembangan Gini Rasio Perdesaan Selama Periode 2007-2017.

Berdasarkan hasil evaluasi pada tahun 20152016, Dana Desa terbukti telah menghasilkan sarana/prasarana yang bermanfaat bagi masyarakat. Diantaranya yaitu pembangunan jalan desa sepanjang 95.2 ribu $\mathrm{km}$, jembatan sepanjang 914 ribu meter, sambungan air bersih sebanyak 22616 unit, embung desa sebanyak 1 338 unit, polindes sebanyak 4004 unit, pasar desa sebanyak 3106 unit, PAUD Desa 14957 unit, sumur 19485 unit, dan drainase/irigasi sebanyak 103405 unit (Kementrian Keuangan, 2017). Hasil evaluasi penggunaan Dana Desa selama dua tahun terakhir juga menunjukkan bahwa Dana Desa telah berhasil meningkatkan kualitas hidup masyarakat desa dan pemerataan pendapatan di perdesaan. Hal ini dapat dilihat 
dari peningkatan penuruna rasio gini dari tahun 2014 (0.34) menjadi 0.32 (2017). Sejak diberlakukannya Dana Desa terjadi penurunan Rasio Gini di perdesaan dari 0.34 tahun 2014 menjadi 0.32 tahun 2017.

Realisasi dana desa yang telah dikucurkan pada 2017 mencapai Rp 60 triliun yang ditransfer ke 74910 desa di 33 provinsi. Jawa Tengah merupakan provinsi yang menerima dana desa terbesar yang mencapai Rp 1.5 triliun pada tahun 2015 meningkat menjadi $\mathrm{Rp} 4.5$ triliun pada tahun 2017. Sebagai informasi, dana desa merupakan dana yang bersumber dari APBN yang diperuntukan bagi desa dan ditransfer melalui APBD Kabupaten/Kota. Dana tersebut digunakan untuk membiayai penyelenggaran pemerintahan daerah, pelaksanaan pembangunan, pembinaan dan pemberdayaan masyarakat.

Tabel 1. Perkembangan Alokasi Dana Desa Tahun 2015 dan 2017

\begin{tabular}{|c|c|c|c|c|}
\hline \multirow{2}{*}{ Provinsi } & \multicolumn{2}{|c|}{ Jumlah Desa } & \multicolumn{2}{|c|}{ Jumlah Dana (Milyar Rp) } \\
\hline & 2015 & 2017 & 2015 & 2017 \\
\hline Aceh & 6474 & 6497 & 1708 & 4893 \\
\hline Bali & 636 & 636 & 185 & 537 \\
\hline Bangka Belitung & 309 & 309 & 92 & 262 \\
\hline Banten & 1238 & 1238 & 353 & 1010 \\
\hline Bengkulu & 1341 & 1341 & 363 & 1035 \\
\hline Daerah Istimewa Yogyakarta & 392 & 392 & 128 & 369 \\
\hline Gorontalo & 657 & 657 & 180 & 514 \\
\hline Jambi & 1398 & 1399 & 382 & 1091 \\
\hline Jawa Barat & 5319 & 5312 & 1590 & 4548 \\
\hline Jawa Tengah & 7809 & 7809 & 2229 & 6384 \\
\hline Jawa Timur & 7723 & 7724 & 2214 & 6340 \\
\hline Kalimantan Barat & 1908 & 2031 & 537 & 1617 \\
\hline Kalimantan Selatan & 1864 & 1865 & 501 & 1430 \\
\hline Kalimantan Tengah & 1434 & 1434 & 403 & 1149 \\
\hline Kalimantan Timur & 833 & 841 & 241 & 692 \\
\hline Kalimantan Utara & 447 & 447 & 130 & 370 \\
\hline Kepulauan Riau & 275 & 275 & 79 & 228 \\
\hline Lampung & 2435 & 2435 & 685 & 1957 \\
\hline Maluku & 1191 & 1198 & 334 & 962 \\
\hline Maluku Utara & 1063 & 1064 & 291 & 832 \\
\hline Nusa Tenggara Barat & 995 & 995 & 302 & 865 \\
\hline Nusa Tenggara Timur & 2950 & 2996 & 813 & 2360 \\
\hline Papua & 5118 & 5420 & 1433 & 4301 \\
\hline Papua Barat & 1628 & 1743 & 449 & 1364 \\
\hline Riau & 1592 & 1592 & 446 & 1269 \\
\hline Sulawesi Barat & 576 & 575 & 162 & 461 \\
\hline Sulawesi Selatan & 2253 & 2257 & 635 & 1821 \\
\hline Sulawesi Tengah & 1839 & 1842 & 500 & 1434 \\
\hline Sulawesi Tenggara & 1820 & 1917 & 496 & 1482 \\
\hline Sulawesi Utara & 1490 & 1507 & 403 & 1161 \\
\hline Sumatera Barat & 880 & 885 & 267 & 797 \\
\hline Sumatera Selatan & 2817 & 2859 & 775 & 2267 \\
\hline Sumatera Utara & 5389 & 5418 & 1461 & 4198 \\
\hline Total & 74093 & 74910 & 20766 & 60000 \\
\hline
\end{tabular}

Sumber: Kemendesa, 2019 
Beberapa penelitian terdahulu telah dilakukan terkait dengan dana desa, diantaranya Azwardi dan Sukanto (2014) yang menunjukan bahwa alokasi dana desa dapat menurunkan angka penduduk miskin dan menciptakan kesejahteraan masyarakat. Rio, Femmy dan Telly (2015) membuktikan bahwa Pemanfaatan alokasi dana desa dapat meningkatkan partisipasi masyarakat dalam pembagunan khusunya pada kasus Desa Tanjung Sidupa Kecamatan Pinogaluman Kabupaten Bolang Mongondow Utara. Belum ada yang melihat bagaimana keterkaitan antara dana desa dengan disparitas harga (bawang merah dan cabai merah).

\section{Disparitas Harga Bawang Merah dan Cabai Merah}

Hasil analisis menunjukkan bahwa disparitas harga komoditas bawang merah pada 33 provinsi di Indonesia (2013-2017). Pada tahun 2013 terjadi disparitas harga komoditas bawang merah pada tingkat nasional sebesar 18.31 persen, dimana termasuk dalam kategori disparitas sedang. Harga bawang merah tertinggi sebesar Rp 49 111,-/kg terdapat di Provinsi Papua Barat. Harga bawang merah terendah sebesar Rp 24 295,-/kg terdapat di Provinsi Kep. Riau. Terjadinya perbedaan harga diakibatkan oleh pendapatan perkapita, harga barang input, serta jarak ekonomi (BI 2013). Disisi lain, persentase selisih antara harga tertinggi dengan harga terendah sebesar 102.14 persen yang menunjukkan terjadinya disparitas tinggi diantara harga tertinggi dan terendah untuk komoditas bawang merah pada tahun 2013. Tingkat disparitas yang tinggi juga dapat dilihat dari selisih antara harga tertinggi dengan harga ratarata nasional yang menunjukkan nilai sebesar 43.12 persen.

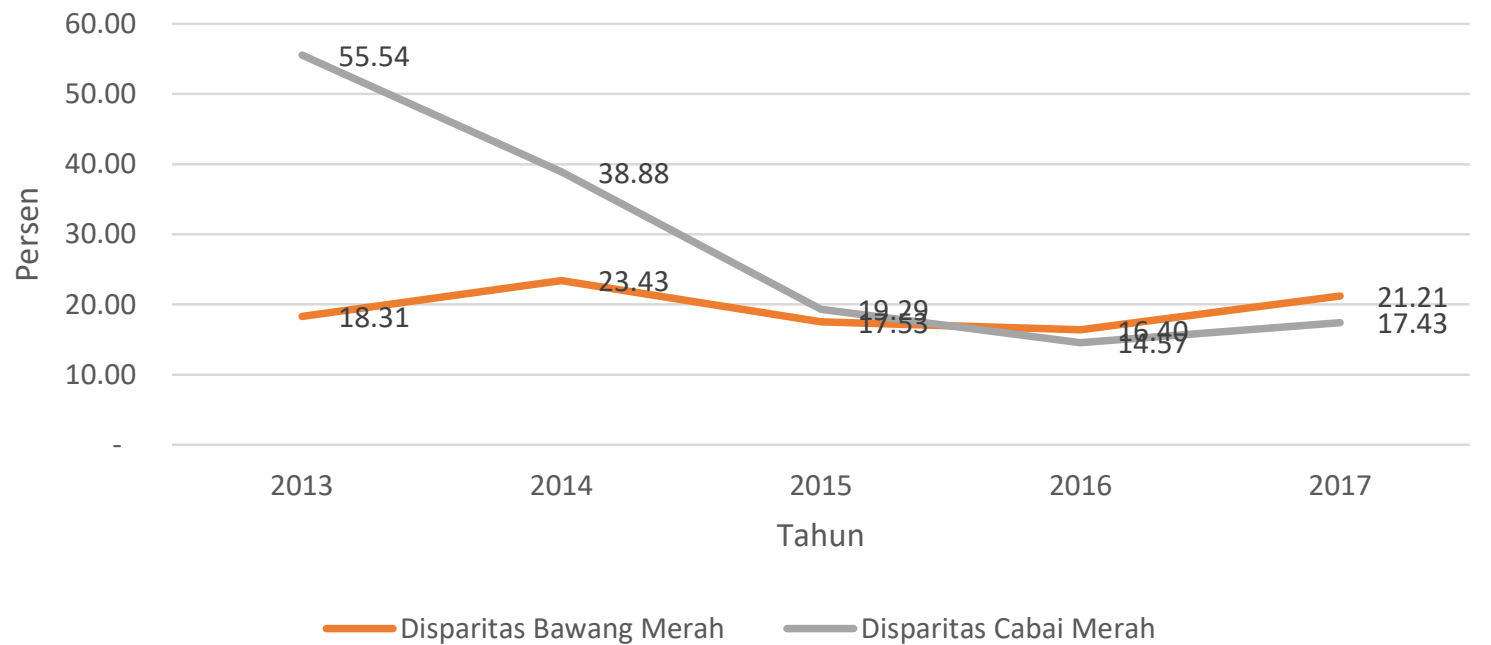

Gambar 5. Tingkat Disparitas Harga Bawang Merah dan Cabai Merah

Tahun 2014 terjadi disparitas harga komoditas bawang merah pada tingkat nasional sebesar 23.43 persen, dimana termasuk dalam kategori disparitas tinggi. Harga bawang merah tertinggi sebesar Rp 39.480,-/kg terdapat di Provinsi Papua Barat. Harga bawang merah terendah sebesar Rp 15.539,-/kg terdapat di Provinsi Jawa Timur. Disisi lain, persentase selisih antara harga tertinggi dengan harga terendah sebesar 154.07 persen yang menunjukkan terjadinya disparitas tinggi diantara harga tertinggi dan terendah untuk komoditas bawang merah pada tahun 2014. Tingkat disparitas yang tinggi juga dapat dilihat dari selisih antara harga tertinggi dengan harga rata-rata nasional yang menunjukkan nilai sebesar 74.42 persen.

Produksi bawang merah hanya terkonsentrasi di 4 provinsi sentra Brebes, Solok, Bandung, Majalengka, Cirebon, Brebes, Tegal, Kendal, Demak, Bima, Pati, Nganjuk, Probolinggo, dan Enrekang. Produksi bawang merah bulanan cenderung berfluktuasi, di sisi lain, kebutuhan masyarakat pada komoditas ini cenderung tetap setiap bulannya. Kondisi tersebut menyebabkan terjadinya disparitas atau ketidakmerataan harga bawang merah. Disparitas harga mengindikasikan adanya sistem manajemen pasokan yang kurang baik, terutama permasalahan distribusi pasokan 
dari daerah sentra produksi ke daerah lainnya untuk memenuhi kebutuhan bawang merah di masing-masing daerah. Permasalahan lainnya adalah kendala jauhnya jarak, besarnya biaya logistik untuk menyalurkan bawang merah dari sentra produksi ke seluruh wilayah-wilayah di pelosok, kondisi infrastruktur yang belum memadai terutama di pelosok serta masih minimnya teknologi untuk memperpanjang masa simpan bawang merah agar tidak busuk sebelum sampai ke tangan konsumen di seluruh Indonesia. Kondisi disparitas harga terbagi menjadi dua, yaitu kondisi disparitas antar waktu dan kondisi disparitas antar provinsi yang ada di Indonesia. Disparitas harga antar waktu menggambarkan keragaman harga bulanan secara nasional dalam tiga bulan atau 1 kuartal, sedangkan disparitas harga antar provinsi menggambarkan keragaman harga di provinsi-provinsi yang ada di Indonesia.

Tabel 2. Perkembangan Harga Konsumen Komoditas Bawang Merah $(\mathrm{Rp} / \mathrm{Kg})$ Dan Disparitas Nasional (Persen) Periode 2013-2017

\begin{tabular}{|c|c|c|c|c|c|c|}
\hline No & Provinsi & 2013 & 2014 & 2015 & 2016 & 2017 \\
\hline 1 & Aceh & 34303.00 & 24022.00 & 27729.00 & 39830.00 & 31109.00 \\
\hline 2 & Bali & 31082.00 & 19234.00 & 23137.00 & 35852.00 & 31994.00 \\
\hline 3 & Banten & 31069.00 & 21959.00 & 24654.00 & 37428.00 & 31490.00 \\
\hline 4 & Bengkulu & 38500.00 & 26452.00 & 28367.00 & 44465.00 & 34672.00 \\
\hline 5 & DI Yogyakarta & 27677.00 & 16629.00 & 19782.00 & 32232.00 & 28022.00 \\
\hline 6 & DKI Jakarta & 32130.00 & 21571.00 & 24926.00 & 39703.00 & 36056.00 \\
\hline 7 & Gorontalo & 39521.00 & 24610.00 & 26665.00 & 42730.00 & 34104.00 \\
\hline 8 & Jambi & 32778.00 & 17524.00 & 21054.00 & 32161.00 & 24439.00 \\
\hline 9 & Jawa Barat & 31103.00 & 19135.00 & 23776.00 & 39898.00 & 33285.00 \\
\hline 10 & Jawa Tengah & 25756.00 & 15776.00 & 19381.00 & 31291.00 & 26859.00 \\
\hline 11 & Jawa Timur & 27142.00 & 15539.00 & 18423.00 & 33016.00 & 28760.00 \\
\hline 12 & Kalimantan Barat & 26700.00 & 19892.00 & 24811.00 & 40338.00 & 33128.00 \\
\hline 13 & Kalimantan Selatan & 34595.00 & 19906.00 & 22724.00 & 38141.00 & 29973.00 \\
\hline 14 & Kalimantan Tengah & 34885.00 & 20944.00 & 24569.00 & 41583.00 & 34586.00 \\
\hline 15 & Kalimantan Timur & 37712.00 & 23153.00 & 24776.00 & 40509.00 & 30557.00 \\
\hline 16 & Kep. Bangka Belitung & 36665.00 & 22184.00 & 26239.00 & 41090.00 & 35245.00 \\
\hline 17 & Kep. Riau & 24295.00 & 22945.00 & 26437.00 & 28697.00 & 28661.00 \\
\hline 18 & Lampung & 31562.00 & 16941.00 & 20525.00 & 33599.00 & 27245.00 \\
\hline 19 & & 41071.00 & 24858.00 & 27400.00 & 44831.00 & 38632.00 \\
\hline 20 & Mal & 45166.00 & 33124.00 & 34915.00 & 53941.00 & 49928.00 \\
\hline 21 & Nasional & 34315.42 & 22634.58 & 25186.12 & 38992.30 & 33337.70 \\
\hline 22 & Nusa Tenggara Barat & 30262.00 & 17917.00 & 20155.00 & 33809.00 & 28965.00 \\
\hline 23 & Nusa Tenggara Timur & 30684.00 & 23348.00 & 20004.00 & 33387.00 & 42490.00 \\
\hline 24 & Papua & 43658.00 & 33479.00 & 34483.00 & 51770.00 & 49947.00 \\
\hline 25 & Papua Barat & 49111.00 & 39480.00 & 37242.00 & 52711.00 & 52584.00 \\
\hline 26 & Riau & 27867.00 & 17734.00 & 20489.00 & 30291.00 & 23883.00 \\
\hline 27 & Sulaw & 37768.00 & 25021.00 & 27197.00 & 41900.00 & 32901.00 \\
\hline 28 & Sulawesi Selata & 33573.00 & 21456.00 & 23059.00 & 37095.00 & 30663.00 \\
\hline 29 & Sulawesi Tengah & 40106.00 & 25849.00 & 26164.00 & 41844.00 & 31207.00 \\
\hline 30 & Sulawesi Tenggara & 45134.00 & 29115.00 & 28817.00 & 42654.00 & 37802.00 \\
\hline 31 & Sulawesi Utara & 42205.00 & 27327.00 & 29999.00 & 46066.00 & 38539.00 \\
\hline 32 & Sumatra Barat & 26404.00 & 18080.00 & 22114.00 & 28996.00 & 22365.00 \\
\hline 33 & Sumatra Selatan & 33866.00 & 20744.00 & 25926.00 & 40675.00 & 34071.00 \\
\hline \multirow[t]{5}{*}{34} & Sumatra Utara & 28059.00 & 20993.00 & 25203.00 & 34213.00 & 25982.00 \\
\hline & Nasional & 34315.42 & 22634.58 & 25186.12 & 38992.30 & 33337.70 \\
\hline & Haı & 24295.00 & 15539.00 & 18423.00 & 28697.00 & 22365.00 \\
\hline & Harga Tertinggi & 49111.00 & 39480.00 & 37242.00 & 53941.00 & 52584.00 \\
\hline & $\begin{array}{l}\text { Disparitas Nasional } \\
\text { (persen) }\end{array}$ & 18.31 & 23.43 & $\mathbf{1 7 . 5 3}$ & 16.40 & 21.21 \\
\hline
\end{tabular}


Disparitas harga bawang merah antar provinsi tahun 2015 dan 2016 menunjukkan pola fluktuasi yang relatif sama dari bulan ke bulan, kecuali bulan September dimana pada tahun 2016 meningkat dari bulan sebelumnya sedangkan pada tahun 2015 menurun dari sebelumya.

Tabel 31. Perkembangan Harga Konsumen Komoditas Cabai Merah $(\mathrm{Rp} / \mathrm{Kg})$ Dan Disparitas Nasional (Persen) Periode 2012-2016

\begin{tabular}{|c|c|c|c|c|c|c|}
\hline No & Provinsi & 2012 & 2013 & 2014 & 2015 & 2016 \\
\hline 1 & Aceh & 83826 & 68143 & 41848 & 36826 & 37852 \\
\hline 2 & Bali & 37335 & 43321 & 40273 & 36855 & 39994 \\
\hline 3 & Banten & 68312 & 53047 & 44908 & 45831 & 50394 \\
\hline 4 & Bengkulu & 148551 & 97369 & 58144 & 56273 & 51657 \\
\hline 5 & DI Yogyakarta & 44450 & 40077 & 35116 & 42026 & 43380 \\
\hline 6 & DKI Jakarta & & 30100 & 46917 & 52023 & 39657 \\
\hline 7 & Gorontalo & 61966 & 50616 & 48540 & 43792 & 39125 \\
\hline 8 & Jambi & 72526 & 62199 & 45576 & 44914 & 39597 \\
\hline 9 & Jawa Barat & 37795 & 33795 & 35160 & 41209 & 42711 \\
\hline 10 & Jawa Tengah & 50583 & 42761 & 37233 & 42244 & 48686 \\
\hline 11 & Jawa Timur & 40561 & 42617 & 37772 & 44796 & 56494 \\
\hline 12 & Kalimantan Barat & 47884 & 47074 & 44245 & 46916 & 48656 \\
\hline 13 & Kalimantan Selatan & 51556 & 51526 & 52734 & 49358 & 48058 \\
\hline 14 & Kalimantan Tengah & 52552 & 56692 & 51159 & 50491 & 51714 \\
\hline 15 & Kalimantan Timur & 56732 & 65187 & 58561 & 49163 & 43606 \\
\hline 16 & Kep. Bangka Belitung & 59584 & 70242 & 59751 & 59848 & 56880 \\
\hline 17 & Kep. Riau & 44860 & 38735 & 39644 & 47550 & 51835 \\
\hline 18 & Lampung & 34253 & 38684 & 40950 & 41902 & 34269 \\
\hline 19 & Maluku & 92923 & 82264 & 47629 & 36492 & 34882 \\
\hline 20 & Maluku Utara & 33426 & 36004 & 39274 & 37038 & 43509 \\
\hline 21 & Nusa Tenggara Barat & 44364 & 43958 & 34339 & 32681 & 36537 \\
\hline 22 & Nusa Tenggara Timur & 28027 & 32443 & 37015 & 38308 & 37888 \\
\hline 23 & Papua & 44229 & 43258 & 44088 & 49326 & 64496 \\
\hline 24 & Papua Barat & 63228 & 79754 & 60896 & 47848 & 55047 \\
\hline 25 & Riau & 64738 & 61827 & 48859 & 46696 & 50013 \\
\hline 26 & Sulawesi Barat & 18448 & 32989 & 37206 & 32925 & 29687 \\
\hline 27 & Sulawesi Selatan & 14759 & 22766 & 29581 & 38227 & 41218 \\
\hline 28 & Sulawesi Tengah & 32491 & 41817 & 43601 & 39174 & 33946 \\
\hline 29 & Sulawesi Tenggara & 42972 & 53164 & 47550 & 43775 & 37101 \\
\hline 30 & Sulawesi Utara & 16766 & 20254 & 29890 & 44101 & 46641 \\
\hline 31 & Sumatra Barat & 119826 & 97750 & 57109 & 49833 & 47231 \\
\hline 32 & Sumatra Selatan & 112588 & 85581 & 56610 & 53142 & 50805 \\
\hline 33 & Sumatra Utara & 35291 & 29064 & 36948 & 37204 & 39824 \\
\hline & Nasional & 54918.81 & 51366.00 & 44518.97 & 44205.67 & 44648.18 \\
\hline & Harga Tertinggi & 148551.00 & 97750.00 & 60896.00 & 59848.00 & 64496.00 \\
\hline & Harga Terendah & 14759.00 & 20254.00 & 29581.00 & 32681.00 & 29687.00 \\
\hline & $\begin{array}{l}\text { Disparitas Nasional } \\
\text { (persen) }\end{array}$ & 55.54 & 38.88 & 19.29 & 14.57 & 17.43 \\
\hline
\end{tabular}


Disparitas harga bawang merah antar provinsi pada tahun 2016 selalu lebih tinggi dibandingkan tahun 2015 pada tiap bulan yang sama, kecuali pada bulan April, Mei dan Desember dimana disparitas tahun 2016 lebih tinggi dibanding tahun 2015. Selama kurun waktu Januari 2015 hingga September 2016, disparitas harga bawang merah antar provinsi terendah terjadi pada bulan Maret 2016 dengan nilai koefisien keragaman sebesar 11.3 dan disparitas harga bawang merah antar provinsi tertinggi terjadi pada bulan Agustus 2015 dengan nilai koefisien keragaman sebesar 27.6. Tahun 2017 terjadi disparitas harga komoditas bawang merah pada tingkat nasional sebesar 21.21 persen, dimana termasuk dalam kategori disparitas sedang. Harga bawang merah tertinggi sebesar Rp 52 584,-/kg terdapat di Provinsi Papua Barat. Harga bawang merah terendah sebesar Rp 22 365,-/kg terdapat di Provinsi Sumatra Barat.

Disisi lain, persentase selisih antara harga tertinggi dengan harga terendah sebesar 87.97 persen yang menunjukkan terjadinya disparitas tinggi diantara harga tertinggi dan terendah untuk komoditas bawang merah pada tahun 2017. Tingkat disparitas yang tinggi juga dapat dilihat dari selisih antara harga tertinggi dengan harga rata-rata nasional yang menunjukkan nilai sebesar 38.34 persen.

Sedangkan untuk disparitas harga komoditas cabai merah di tingkat harga konsumen beserta nilai disparitas harga nasional untuk komoditas cabai merah pada 33 provinsi di Indonesia (2012-2016). Pada tahun 2012 terjadi disparitas harga cabai merah pada tingkat nasional sebesar 55.54 persen, dimana termasuk dalam kategori disparitas sangat tinggi. Harga cabai merah tertinggi sebesar Rp 148 551,-/kg terdapat di Provinsi Bengkulu. Harga cabai merah terendah sebesar Rp 14 759,-/kg terdapat di Provinsi Sulawesi Selatan. Disisi lain, persentase selisih antara harga tertinggi dengan harga terendah sebesar 906.51 persen yang menunjukkan terjadinya disparitas tinggi diantara harga tertinggi dan terendah untuk komoditas cabai merah pada tahun 2012. Tingkat disparitas yang tergolong tinggi juga dapat dilihat dari selisih antara harga tertinggi dengan harga rata-rata nasional yang menunjukkan nilai sebesar 170.50 persen.

Tahun 2013 terjadi disparitas harga cabai merah pada tingkat nasional sebesar 38.88 persen, dimana termasuk dalam kategori disparitas sangat tinggi. Harga cabai merah tertinggi sebesar $\mathrm{Rp} 97.750,-/ \mathrm{kg}$ terdapat di Provinsi Sumatra Barat. Harga cabai merah terendah sebesar Rp 20.254,-/kg terdapat di Provinsi Sulawesi Utara. Disisi lain, persentase selisih antara harga tertinggi dengan harga terendah sebesar 382.62 persen yang menunjukkan terjadinya disparitas tinggi diantara harga tertinggi dan terendah untuk komoditas cabai merah pada tahun 2013. Tingkat disparitas yang tergolong tinggi juga dapat dilihat dari selisih antara harga tertinggi dengan harga rata-rata nasional yang menunjukkan nilai sebesar 90.30 persen.

Tahun 2014 terjadi disparitas harga cabai merah pada tingkat nasional sebesar 19.29 persen, dimana termasuk dalam kategori disparitas sedang. Harga cabai merah tertinggi sebesar Rp 60.896,-/kg terdapat di Provinsi Papua Barat. Harga cabai merah terendah sebesar Rp 29.581,-/kg terdapat di Provinsi Sulawesi Selatan. Disisi lain, persentase selisih antara harga tertinggi dengan harga terendah sebesar 105.86 persen yang menunjukkan terjadinya disparitas tinggi diantara harga tertinggi dan terendah untuk komoditas cabai merah pada tahun 2014. Tingkat disparitas yang tergolong tinggi juga dapat dilihat dari selisih antara harga tertinggi dengan harga ratarata nasional yang menunjukkan nilai sebesar 36.79 persen.

Tidak setiap daerah mampu memenuhi kebutuhan cabai dan bawang merah dari daerah sendiri. Misalnya DKI Jakarta, tidak ada produksi cabe, sehingga untuk memenuhi kebutuhan cabenya harus didatangkan dari daerah lain seperti Jawa Barat, Jawa Tengah, Jawa Timur dan Sumatera Utara sebagai daerah sentra produksi. Oleh karena itu, panjangnya waktu tempuh distribusi dapat memengaruhi meningkatkan biaya distribusi dan biaya susut. Untuk mendistribusikan cabe dari sentra produksi ke DKI Jakarta sebagai sentra konsumsi membutuhkan waktu yang tidak sedikit. Waktu yang dibutuhkan dalam 
distribusi cabe dari Jawa Timur ke DKI Jakarta \pm 12 - 14 jam, dari Jawa Tengah (Brebes) ke DKI Jakarta dibutuhkan waktu $\pm 5-7$ jam dan dari Jawa Barat (Garut) ke DKI Jakarta dibutuhkan waktu $\pm 5-7$ jam.

Mengingat cabe merupakan komoditi yang mudah rusak, maka potensi terjadinya kerusakan sangat dimungkinkan karena busuk sehingga banyak susut yang efeknya adalah biaya distribusi dan biaya susut berpotensi dibebankan kepada harga di tingkat eceran (konsumen). Biaya distribusi dan biaya susut cabe akan semakin besar dalam perdagangan antar pulau dari Jawa Timur ke Kalimantan Selatan atau Kalimantan Timur. Waktu tempuh dalam distribusi cabe dari Surabaya ke Banjarmasin \pm 1 hari, dan jika kembali didistribusikan ke Samarinda dibutuhkan waktu \pm 12 jam. Oleh karena itu, disparitas harga cabe dan bawang merah juga terkait dengan kondisi geografis wilayah, dimana di wilayah yang relatif infrastruktur jalannya tidak baik (terpencil) dibanding wilayah lain, harga cenderung menjadi lebih mahal.

Disparitas harga cabai merah juga terkait dengan kondisi geografis wilayah, dimana di wilayah yang relatif infrastruktur jalannya tidak baik (terpencil) dibanding wilayah lain, harga cabai cenderung lebih mahal. Harga cabai di wilayah yang relatif sulit dijangkau (relatif terpencil) harganya cenderung lebih mahal dibanding harga cabai di wilayah yang mudah dijangkau. Semakin mudah wilayah dijangkau, maka semakin cepat proses distribusinya. Mudah dan tidaknya suatu daerah dijangkau terkait dengan infrastruktur jalan. Semakin baik infrastruktur jalan, harga cabai semakin rendah.

\section{Analisis Korelasi Disparitas Harga dan Dana Desa}

Analisis korelasi adalah teknik statistik yang digunakan untuk menguji ada/tidaknya hubungan serta arah hubungan dari dua variabel atau lebih. Hasil menunjukkan bahwa korelasi antara disparitas harga bawang merah dan cabai merah dengan dana desa rendah dan tidak signifikan. Hal ini dapat terjadi karena program dana desa baru diadakan sejak tahun 2015 sehingga hasilnya masih belum dapat dirasakan. Penggunaan dana desa tidak hanya untuk infrastruktur jalan tapi juga untuk sarana prasaran desa, sosial, serta pelestarian lingkungan hidup. Lebih lanjut, dana desa digunakan untuk pembangunan infrastruktur desa: irigasi desa, drainase, posyandu, mengembangkan koperasi, peternakan desa, dan Badan Usaha Milik Desa. Sehingga, dapat dijelaskan bahwa adanya kecenderungan pergerakan yang sama atau tidak adanya kaitan atau hubungan antara dana desa dan disparitas harga bawang merah dan cabai merah.

Tabel 4. Hasil Analisis Korelasi

\begin{tabular}{|l|r|}
\hline \multicolumn{1}{|c|}{ Indikator } & \multicolumn{1}{|c|}{ Dana Desa } \\
\hline DISPARITAS_BAWANG & -0.10148 \\
\hline DISPARITAS_CABAI & {$[0.5805]$} \\
\hline & 0.20396 \\
\hline
\end{tabular}

Note: [ ] Probability

Padahal menurut penelitian LIPI, agar program tol laut lebih optimal menekan disparitas harga, LIPI merekomendasikan pemerintah untuk memperbaiki akses jalan antar desa di pulau utama yang terintegrasi dengan konsep tol laut. Perbaikan akses jalan bisa mengoptimalkan dana desa. Lalu, untuk menjangkau pulau-pulau kecil, pemerintah bisa memberdayakan pelayaran rakyat sebagai saluran ke pulau-pulau kecil dan alternatif pelayaran perintis. Walaupun demikian, permasalahan disparitas harga bawang merah dan cabai merah lebih banyak disebabkan oleh ketersediaan pasokan pada saat permintaan meningkat. Makna ketersediaan disini adalah barang yang sudah siap dalam jumlah dan kualitas untuk didistribusikan, bukan ketersediaan masih berada di lahan-lahan 
pertanian yang masih belum jelas jumlah dan kualitas yang akan dihasilkannya.

Hasil analisis korelasi ini menunjukkan bahwa dengan adanya pembangunan berbagai infrastruktur dari dana desa seperti jalan desa sepanjang 95.2 ribu km, jembatan sepanjang 914 ribu meter, embung desa sebanyak 1338 unit, pasar desa sebanyak 3106 unit, dan drainase/irigasi sebanyak $103 \quad 405$ unit (Kementerian Keuangan 2017). Infrastruktur tersebut merupakan proksi dari biaya transportasi dan infrastruktur fisik (physical capital) pemasaran yang ternyata belum dapat memengaruhi disparitas harga bawang merah dan cabai merah. Penelitian Varela et al (2012) serta Tarigan dan Syumanjaya (2013) juga menunjukkan bahwa infrastruktur jalan tidak signifikan memengaruhi integrasi pasar bawang merah.

Hal ini juga memperkuat hasil dari penelitian sebelumnya yang menyebutkan bahwa tingginya fluktuasi harga bawang merah disebabkan oleh distribusi yang tidak merata sepanjang tahun serta mekanisme stok yang belum berjalan dengan baik sehingga produksi saat in season tidak mampu mencukupi kebutuhan saat off season (Nuraeni et al 2015), penyimpanan bawang merah menyebabkan susut dan tidak tahan lama (Mudatsir 2015), serta adanya kecenderungan asimetris harga di tingkat produsen dan konsumen (Magfiroh et al 2017). Oleh karena itu, infrastruktur yang juga dibutuhkan adalah terkait dengan pemasaran seperti fasilitas penyimpanan, komunikasi, kredit, dan transportasi.

Dengan demikian dibutuhkan sistem penyimpanan hasil panen bawang merah yang berfungsi sebagai buffer stock untuk mengantisipasi lonjakan permintaan di luar musim panen dan kondisi terjadinya gagal panen. Namun tantangannya adalah sifat bawang merah yang tidak dapat disimpan dalam jangka waktu lama sehingga perlu manajemen logistik yang menerapkan teknologi penyimpanan (cool storage) agar bawang merah dapat disimpan dalam jangka waktu lama (minimal 3 bulan) untuk menyeimbangkan jumlah pasokan bawang merah pada saat di luar musim panen. Faktor lain yang memengaruhi adalah kebijakan manajemen rantai pemasaran cabe merah harus lebih efisien untuk memperkecil disparitas harga di tingkat konsumen dan produsen. Manajemen pasokan dan efisiensi pemasaran akan menurunkan pengaruh harga cabe terhadap laju inflasi, terutama inflasi harga pangan.

Terkait dengan cabai merah, hasil penelitian Sativa (2017) menunjukkan nilai koefisien variasi selisih harga antara produsen dan konsumen sangat berfluktuasi setiap tahunnya bahkan mencapai 100 persen. Ini menunjukkan bahwa terjadi permasalahan di dalam rantai pasok cabai merah, jika melihat tingginya jumlah produksi, namun disparitas harga produsen dan konsumen sangat tinggi. Tidak adanya lembaga pengawasan transaksi yang terjadi di dalam rantai pasok, juga menunjang terjadinya peningkatan harga yang cukup tajam dari harga produsen ke harga konsumen. Disparitas antar wilayah juga menunjukkan bahwa perilaku harga cabai merah antar wilayah seringkali menunjukkan variasi harga yang tinggi terutama pada bulan-bulan dengan curah hujan tinggi sehingga berdampak pada penurunan jumlah produksi cabai merah. Jumlah daerah sentra cabai merah yang tidak banyak juga berdampak pada beragamnya harga cabai merah, sehingga daerah non sentra bergantung dari jumlah pasokan cabai merah daerah sentra. Faktor cuaca juga memiliki peran dalam terjadinya fluktuasi harga. Penelitian Fitriana (2016) dan Saptana et al 2012) menyebutkan bahwa produksi cabai merah sangat dipengaruhi oleh iklim.

Menurut Sativa (2017), upaya mengatasi disparitas harga cabai merah antar wilayah dapat dilakukan dengan pemerataan ketersediaan pasokan cabai merah baik dengan meningkatkan luas tanam di daerah non sentra maupun memperbaiki rantai pasok cabai merah. Untuk mengatasi perbedaan harga yang tinggi antara harga produsen dan konsumen, dapat dilakukan dengan pengawasan yang lebih baik oleh pemerintah dalam pelaksanaan transaksi disetiap pelaku rantai pasok maupun jalur distribusinya, memotong mata rantai yang terlalu panjang serta melakukan operasi pasar pada saat harga meningkat tidak wajar. Beberapa kebijakan lain yang perlu diambil, yaitu kebijakan stabilisasi yang bertujuan untuk menghadapi kondisi perdagangan bawang merah internasional, dan fluktuasi harga 
domestik. Instrument/mekanisme dalam kebijakan ini adalah perumusan dan penetapan harga referensi dengan menentukan harga pokok minimum atau harga pokok pemerintah (HPP) pada produk bawang merah, penetapan jendela waktu impor yang tepat dan sesuai dengan ketersediaan di sentra produksi dan konsumsi, monitoring ketersediaan di sentra produksi dan konsumsi sebagai indikator kebijakan impor, mekanisme resi gudang untuk mengantisipasi fluktuasi pasokan, dan mekanisme operasi pasar pada saat harga tinggi. Kebijakan sistem produksi diperlukan untuk mengatasi pasokan yang masih tergantung musim dan fluktuasi harga, dan harga domestik yang jauh lebih tinggi dari harga internasional. Instrument/mekanisme dalam kebijakan ini adalah peningkatan produktivitas dan kualitas bawang merah melalui pengembangan iptek, penggunaan teknologi rainshelter dan irigasi, penerapan sistem manajemen rantai pasok yang tepat, Penerapan standardisasi kualitas dan kemasan yang didorong dari kententuan pasar perkotaan, manajemen logistik untuk meningkatkan efisiensi.

\section{KESIMPULAN DAN SARAN}

\section{Kesimpulan}

1. Temuan menunjukkan bahwa kesenjangan harga antar provinsi masih terjadi, terutama di wilayah timur dan barat. Papua adalah harga tertinggi di sebagian besar komoditas. Tingkat disparitas harga bawang merah di level nasional paling tinggi pada tahun 2017 (21.21 persen) dan paling rendah tahun 2013 (18.31 persen). Sedangkan tingkat disparitas harga cabai merah di level nasional adalah tertinggi tahun 2013 (55.45 persen) dan terendah tahun 2017 (17.43 persen). Rata-rata disparitas harga bawang merah adalah 19.37 persen dan cabai merah sebesar 29.14 persen. Secara umum, kesenjangan nasional masih relatif moderat.

2. Berdasarkan analisis korelasi, hubungan disparitas harga bawang merah dan cabai merah dengan dana desa rendah dan tidak signifikan. Artinya, belum ada kaitan langsung dan pengaruh langsung antara dana desa dan disparitas harga bawang merah dan cabai merah.

\section{Saran}

Untuk dapat menyelesaikan masalah disparitas harga bawang merah dan cabai merah ini adalah dengan memperbaiki sistem manajemen logistik dan distribusi ke setiap daerah di seluruh Indonesia. Namun, buruknya kelembagaan pasar dan tingginya biaya transaksi menjadi pelengkap rendahnya stabilitas pangan barang kebutuhan pokok di Indonesia. Untuk dapat mengendalikan harga bawang merah, pemerintah dan stakeholder tidak mungkin hanya berharap dari persediaan yang ada di lahan dan berharap dari cadangan bawang yang ada di petani, pedagang pengumpul, dan pedagang besar. Untuk itu diperlukan stock/persediaan di gudang atau cold storage milik pemerintah atau perusahaan milik negara yang dapat mempertahankan kualitas bawang merah dengan jumlah yang memadai untuk mencukupi kebutuhan bawang merah seluruh daerah di Indonesia. Dana desa sebaiknya juga digunakan untuk membangun infrastruktur yang terkait dengan pemasaran seperti fasilitas penyimpanan, komunikasi, dan kredit.

\section{DAFTAR PUSTAKA}

Abidin, Z. 2015. Tinjauan Atas Pelaksanaan Keuangan Desa Dalam Mendukung Kebijakan Dana Desa. Jurnal Ekonomi \& Kebijakan Publik, Vol. 6, No. 1, Hal: 6176.

Azwardi dan Sukanto. 2014. Efektifitas Alokasi Dana Desa (ADD) dan Kemiskinan di Provinsi Sumatera Selatan. Jurnal Ekonomi Pembangunan, Vol.12, No.(1), Hal: 29-41.

[BPS] Badan Pusat Statistik. 2018. Berita Resmi Statistik: Perkembangan Indeks Harga Konsumen/Inflasi. Perkembangan Indeks Harga Konsumen/Inflasi No. 01/01/Th. XXI, 2 Januari 2018.

Delam, J, Lis P, Dwi I. 2016. Penggunaan Dana Desa Mekanisme dan Problematik. Jakarta: PT. Sulaksana Watinsa Indonesia. 
Fazri, M, Yulya A, Uke T. 2019. Does Village Fund Have An Impact Toward Economic Growth: A Study Comparative In 416 District In Indonesia With Data Panel Approach. Paper dipresentasikan pada IRSA Conference.

Kementerian Keuangan RI. 2017. Buku Saku Dana Desa. https://www.kemenkeu.go.id/media/675 0/buku-saku-dana-desa.pdf. Akses Tanggal 15 Juli 2019.

Kementerian Perdagangan. 2016. Profil Komoditas Bawang Merah. Direktorat Jenderal Perdagangan Dalam Negeri Kementerian Perdagangan.

LIPI. 2017. LIPI: Tol Laut Masih Kurang Menekan Disparitas Harga. http://lipi.go.id/lipimedia/LIPI-TOLLAUT-MASIH-KURANGMENEKAN-DISPARITASHARGA/18930. Akses Tanggal 6 Juni 2019.

Magfiroh I, Rahman R, Setawati I, dan Zainuddin A 2017. Respon Harga Produsen terhadap Perubahan Harga Konsumen Bawang Merah di Indonesia. Jurnal Sosial Ekonomi Pertanian. Vol 10, No.3, Hal: 7-14.

Mahfudz. 2009. Analisis Dampak Alokasi Dana Desa (ADD) terhadap Pemberdayaan Masyarakat dan Kelembagaan Desa. Jurnal Organisasi dan Manajemen, Vol.5, No.(1), Hal:10-22.

Mudatsir. 2015. Membangun Sistem Logistik Bawang Merah. Disampaikan pada Pertemuan Penguatan Asosiasi Cabe dan Bawang Merah. Bandung: Dinas Pertanian Tanaman Pangan.

Nuraeni D, Anindita R, dan Syafrial. 2015. Analisis Variasi Harga dan Integrasi Pasar Bawang Merah di Jawa Barat. HABITAT. Vol 26, No. 3, Hal: 163-172.

Nurudeen A, Usman A. 2010. Government Expenditure And Economic Growth In Nigeria, 1970-2008: A Disaggregated
Analysis. Business and Economics Journal. 2010(4): Hal:1-7.

Astuti Rahmawati ; Anna Fariyanti; Amzul Rifin. 2019. Faktor Penentu Integrasi Pasar Spasial Bawang Merah di Indonesia. AGRISEP Vol. 18, No. 1, Hal: 31-40.

Republika. 2019. ICW: Dana Desa Paling Rawan di Korupsi. https://www.republika.co.id/berita/nasi onal/hukum/19/02/08/pmlnvn382-icwdana-desa-paling-rawan-dikorupsi [dikases tanggal: 10 Juni 2019]

Rio, Armando T, Femmy T, dan Telly S. 2015. Pemanfaatan Alokasi Dana Desa (Add) Dalam Pembangunan Desa Didesa Tanjung Sidupa Kecamatan Pinogaluman Kabupaten Bolaang Mongondow Utara. Jurnal Administrasi Publik, Vol 4, No 32 (2015).

Sartika, C. Yan, B, dan Wali, A,R.2016. Studi Faktor-faktor penyebab Kemiskinan masyarakat desa Lohia Kabupaten Muna. Junal Ekonomi. Vol.1 (1), Hal: 106-108.

Sativa, M. 2017. Analisis Disparitas dan Dampak Kebijakan Pemerintah Terhadap Pergerakan Harga Cabai Merah di Indonesia. Skripsi: Institut Pertanian Bogor.

Susilowati, Nilam I, Dwi S, dan Syamsul H. 2017. Pengaruh Alokasi Dana Desa, Dana Desa, Belanja Modal, Dan Produk Domestik Regional Bruto Terhadap Kemiskinan Kabupaten/Kota Di Jawa Timur. Jurnal Ilmu Ekonomi Vol 1 Jilid 4/Tahun 2017 Hal. 514-526

Sukirno, S, 2005. Mikro Ekonomi Teori Pengantar, Edisi Ketiga, Raja Grafindo Persada, Jakarta.

Tarigan Sry Devi dan Syumanjaya Rahmat. 2013. Analisis Pengaruh Kualitas Infrastruktur Jalan terhadap HargaHarga Hasil Pertanian di Kecamatan Dolok Silau. Jurnal Ekonomi dan Keuangan. Vol 1, No.6, Hal:70-83.

Widia. 2016. Analisis Marjin Pemasaran Agroindustri Beras di Kecamatan Bungaraya Kabupaten Siak. Jom Faperta Vol.3 No.1, Hal: 1-6. 
DIAN ET AL./ Jurnal Ekonomi dan Kebijakan Pembangunan 8(1):1-19

Varela G, Aldaz C, dan Lacovone L. 2012. Determinants of Market Integration and Price Transmission in Indonesia. Policy
Research Working Paper No 6098. The World Bank. 